\title{
WATER QUALITY OF MELAMCHI RIVER OF SINDHUPALCHOK DISTRICT, CENTRAL NEPAL
}

\author{
ABHA R. MISHRA ${ }^{1} \bowtie$ AND RANJANA GUPTA ${ }^{2}$ \\ ${ }^{1}$ Patan Multiple Campus, Tribhuvan University, Patan Dhoka, Lalitpur, Nepal \\ ${ }^{2}$ Central Department of Zoology, Tribhuvan University, Kirtipur, Kathmandu, Nepal \\ mishraabha@hotmail.com
}

\begin{abstract}
The present study was carried out to estimate the physico-chemical characteristic of Melamchi River from January 2011 to December 2013 with a view to assess the nature and degree of pollution. Melamchi River is a snowmelt and rain fed river. River water is mainly used for drinking and irrigation. Water samples were collected on monthly basis from five sites of river. Parameters analyzed include temperature, electrical conductivity, turbidity, $\mathrm{pH}$, hardness, alkalinity, dissolved oxygen, calcium, magnesium, chloride, phosphate, and nitrate. The study revealed seasonal fluctuations of the factors. River water was well oxygenated and alkaline in nature. High level for turbidity (43.25/ NTU) was observed during monsoon, which exceeded compliance levels of WHO (2011) tolerance limits (5/ NTU) for domestic use. Water contained more TDS and EC indicating the impact of agriculture and deforestation near the river area. The analyzed physico-chemical parameters were found within the permissible limit of WHO, except turbidity. Measures should be taken to regulate agricultural and deforestation activities upriver to avoid advert conditions.
\end{abstract}

Keywords: confluence, seasonal variations, correlation

\section{INTRODUCTION}

Rivers and streams are the best source of water for human, which is not only used for drinking purposes but also for economic growth by power generation, irrigation, aquaculture, recreational fisheries and for domestic use. The anthropogenic activities by human community on these resources are a common phenomenon, which may cause its pollution. It is a common practice for people living along the river catchments to discharge their domestic waste as well as human excreta into rivers. Generally, the pollutants come from three sources i) sewage discharged into the river, ii) industrial effluents discharged into the river without any pretreatment and iii) surface run off from agricultural land where chemical fertilizers, pesticides, insecticides and manures are used. This makes the river water unsafe for human beings and for aquatic organism. The polluted water is one of the main issue and a case of worry for the current scenario. There for its conservation is one of the important duties of the humankind. Water quality can be determined by analyzing physico-chemical properties of water. If physico-chemical properties are at its optimum level, it could be ideal for all the living organisms. Some of the recent research works on physico-chemical characteristics of water bodies were carried out (Sridhar et al., 2006; Pradhan et al., 2009; Srivastava et al., 2009; Haynie et al., 2011; Ghimire et al., 2013; Thapa \& Pal, 2014). 
Melamchi River, a tributary of larger Indrawati River basin, originates from the high snowy mountain of the Jugal Himal at an elevation of $5,875 \mathrm{~m}$. It flows southwards and joins Indrawati River near Melamchi pulbazar at $815 \mathrm{~m}$ elevation. The total length of the Melamchi River is $41 \mathrm{~km}$ and the total catchment area 330 square $\mathrm{km}$. During its course, it receives a number of tributaries like Timbu, Gohore, Gyalthum and Talamarang. Melamchi River Water is utilized for drinking, irrigation, water mills etc. Melamchi River and its tributaries offer an excellent habitat for fishes also, which support local people and fishermen with food, self employment and additional income opportunities.

Regular monitoring of physicochemical parameters is essential to identify magnitude and source of pollution load in this river. Very little information is available in relation to physico-chemical characteristics of Melamchi River water. Hence, the preset study was conducted to assess the status of Melamchi River.

\section{Study area}

In order to determine the water quality of Melamchi River of five sites: Timbu, Gohore, Gyalthum, Talamarang, Pulbazar were chosen for sample collection between Timbu and Melamchi Pulbazar, (fig.1) from January 2011 to December 2013.

\begin{tabular}{|l|l|r|}
\hline \multicolumn{1}{|c|}{ Site } & \multicolumn{1}{|c|}{ Place } & \multicolumn{1}{c|}{ Elevation (Meter) } \\
\hline Sampling Site 1 & Timbu & 1310 \\
\hline Sampling Site 2 & Kiul & 1050 \\
\hline Sampling Site 3 & Gyalthum & 975 \\
\hline Sampling Site 4 & Talamarang & 920 \\
\hline Sampling Site 5 & Melamchi-Pulbazar & 815 \\
\hline
\end{tabular}




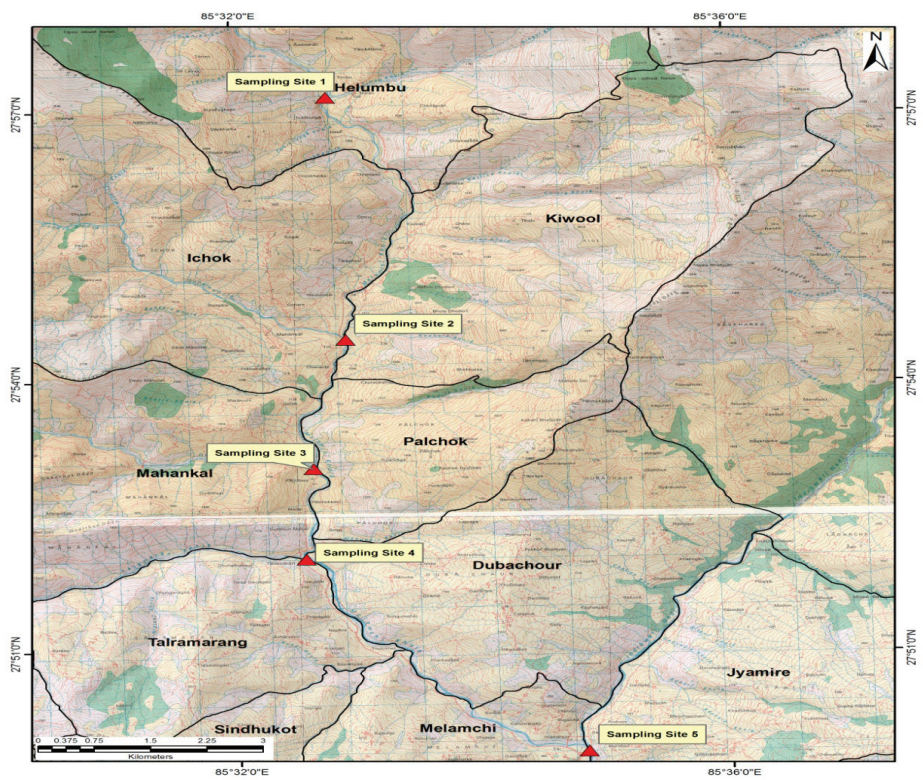

FIG. 1. Map of the study area showing five sampling sites.

\section{MATERIALS AND METHODS}

\section{Sampling and sample analysis}

The investigation was carried out for two years from January 2012 to December 2013. Water samples were collected in first week of every month in $1000 \mathrm{ml}$ clean PVC bottle from each site. The collected samples were brought to the Melamchi Water Supply Project laboratory, Melamchi. Analysis of various factors of water was done within twenty-four hours of collection. Water temperature, electrical conductivity $(\mu \mathrm{S} / \mathrm{cm}), \mathrm{pH}$, dissolved Oxygen $(\mathrm{mg} / \mathrm{l})$, total dissolved solids (mg/l), and turbidity (NTU) were measured on the spot. Water temperature $\left({ }^{\circ} \mathrm{C}\right.$ ), was measured with the help of ordinary mercury thermometer by placing it inside the water at the depth of $1 \mathrm{ft}$. Electric Conductivity was measured by conductivity meter (Russell RL060C portable conductivity meter). DO by DO meter (Orion 3 star portable DO meter), electrical conductivity and total dissolved solids by conductivity meter (Orion 3 star portable conductivity meter), $\mathrm{pH}$ by $\mathrm{pH}$ meter (Orion 3 star portable pH meter), and turbidity by turbidity meter (Orion AQ3010) of Thermo Electron Corporation. Total alkalinity $(\mathrm{mg} / \mathrm{l})$ of water sample is determined by titrating it against standard acid solution using indicators like phenolphthalein and methyl orange. Total hardness ( $\mathrm{mg} / \mathrm{l})$ was determined by using EDTA titrametric method. $100 \mathrm{ml}$ of sample was titrated by $0.01 \mathrm{M}$ EDTA solution after the addition of indicator (very small amount of EBD +1 $\mathrm{ml}$ of ammonia buffer). Calcium ( $\mathrm{mg} / \mathrm{l}$ ) and magnesium ( $\mathrm{mg} / \mathrm{l}$ ) content was determined by EDTA titrametric using $\mathrm{NaOH}$ solution and Murexide indicator. The chloride content $(\mathrm{mg} / \mathrm{l})$ of water sample was determined by titrating the water sample against $0.02 \mathrm{M}$ silver nitrate solution using potassium chromate as an indicator. Nitrate $(\mathrm{mg} / \mathrm{l})$ was determined by Brucine Absorbtivity method and phosphate (mg/l) by spectrophotometric method (APHA, 2005). 


\section{Data analysis}

Whole observation period was divided into three fixed seasons: pre-monsoon (January, February, March, and April), monsoon (May, June July, and August), and post- monsoon (September, October, November and December). Only one Sample (data) was taken every month. Four months data of each season were brought together to calculate Seasonal mean values. The computation was achieved within the framework of $R$ ( $R$ Core Team 2015) to determine the mean. Pearson's $r$ correlation was carried out in order to know the nature and magnitude of the relationship among various physico-chemical parameters.

\section{RESULTS AND DISCUSSION}

Water temperature ranged from $11^{\circ} \mathrm{C}$ to $23^{\circ} \mathrm{C}$ in 2012 and $13^{\circ} \mathrm{C}$ to $23^{\circ} \mathrm{C}$ in 2013 at five sites (fig. 2). High seasonal variations were observed. Temperature showed the highest value in monsoon (summer) at site 5 and lowest value in post-monsoon (winter) at site 1. Electrical conductivity in natural water is the normalized measure of the water's ability to conduct electric current. Dissolved salts present in water bodies mostly influence this. The Electrical conductivity (EC) values of water samples ranged from 169-319 $\mu \mathrm{s} / \mathrm{cm}$ in 2012 and 163-308 $\mu \mathrm{s} / \mathrm{cm}$. in 2013 (Fig 3). EC showed high value in pre-monsoon at three sites and low value at site 2 and 3 in post-monsoon. In the present study water turbidity value ranged from 1.50/NTU to 43.25/ NTU in 2012, and 25-43/ NTU in 2013 (fig. 4). Turbidity was lowest in pre -monsoon at site 1 and highest in monsoon at site 1 and 5 . During present study pH value of water ranged between 8.01-8.40 in the year 2012 and 7.29-8.54 in 2013. pH value showed alkaline nature throughout the study period (fig. 5) at all sites. Season wise analysis of pH showed maximum in monsoon at site 3 and minimum at site 4 in post-monsoon. The amount of dissolved oxygen varied from $6.68 \mathrm{mg} / \mathrm{l}$ to $10.20 \mathrm{mg} / \mathrm{l}$ in the year 2012 and $6.43 \mathrm{mg} / \mathrm{l} 9.63$ $\mathrm{mg} / \mathrm{l}$ in 2013 (fig. 6). Minimum amount of dissolved oxygen was observed in monsoon at site 4 and maximum was in post-monsoon at site 1 . Total dissolved solids range of water was between 111-200 mg/l in 2012 and $122-204 \mathrm{mg} / \mathrm{l}$ in 2013. The maximum value of TDS was recorded in pre-monsoon at site five and the minimum value was observed in monsoon and post-monsoon at site 3 (fig. 7). TDS value decreased in monsoon, then increased in September, after which the value decreased till January. Total alkalinity of water ranged between 32-43mg/l in 2012 and 26 - 43mg/l in 2013. The minimum value was observed in monsoon at site 3 and maximum value was recorded in post-monsoon at site 1 and 5 (fig. 8). Total hardness of river water ranged between $28-38 \mathrm{mg} / \mathrm{l}$ in 2012 and $24-36 \mathrm{mg} / \mathrm{l}$ in 2013. The maximum value was recorded in pre-monsoon at site 4 and minimum value in monsoon at site 1 (fig. 9). Calcium content of water ranged from $4.16 \mathrm{mg} / \mathrm{I}$ to $7.77 \mathrm{mg} / \mathrm{I}$ during 2012 and $4.29 \mathrm{mg} / \mathrm{I}$ to $7.60 \mathrm{mg} / \mathrm{l}$ during 2013 (fig. 10). It was maximum during pre-monsoon at sight 1 and minimum during monsoon at site 2 . Range of magnesium varied from $2.22 \mathrm{mg} . / \mathrm{I}$ to $5.5 \mathrm{mg} / \mathrm{l}$ in 2012 and $1.00 \mathrm{mg} / \mathrm{I}$ to $4.72 \mathrm{mg} / \mathrm{I}$ during 2013 (fig. 11). It was highest during premonsoon at site 3 and minimum during monsoon at site 2 . The chloride concentration ranged from $2.6 \mathrm{mg} / \mathrm{l}$ to $7.92 \mathrm{mg} / \mathrm{l}$ during 2012 and $3.27 \mathrm{mg} / \mathrm{l}$ to $7.20 \mathrm{mg} / \mathrm{l}$ in 2013 . The minimum concentration of chloride was observed in pre-monsoon at site 2 and maximum at site 4 in post-monsoon (fig.12). Phosphate content in the river water ranged between $0.01 \mathrm{mg} / \mathrm{l}$ and $0.16 \mathrm{mg} / \mathrm{l}$ during 2012. While in 2013 , the value ranged from $0.01 \mathrm{mg} / \mathrm{l}$ to $0.016 \mathrm{mg} / \mathrm{l}$. The 
minimum seasonal mean value was recorded during pre-monsoon while maximum during post-monsoon at all sites in 2012, however it was maximum in pre-monsoon in 2013 (fig. 13). The nitrate content ranged from $0.53 \mathrm{mg} / \mathrm{I}$ to $3.21 \mathrm{mg} / \mathrm{l}$ and $0.81 \mathrm{mg} / \mathrm{I}$ to $4.31 \mathrm{mg} / \mathrm{l}$ in 2012 and 2013. The value of nitrates was recorded lowest during pre-monsoon season at site 1 and highest in post- monsoon season at site 5 (fig. 14).

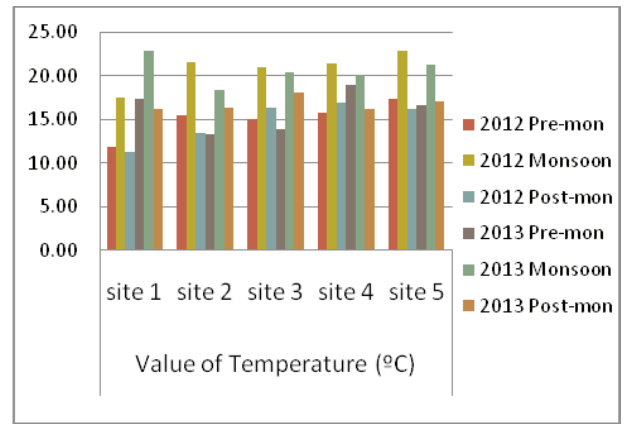

FIG. 2. Seasonal variation in water temperature.

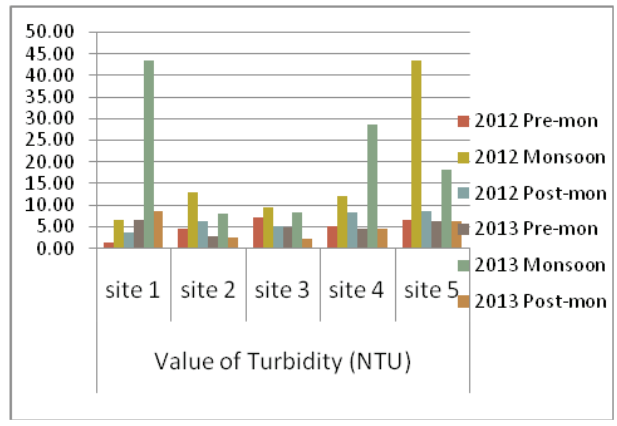

FIG. 4. Seasonal variations in turbidity.

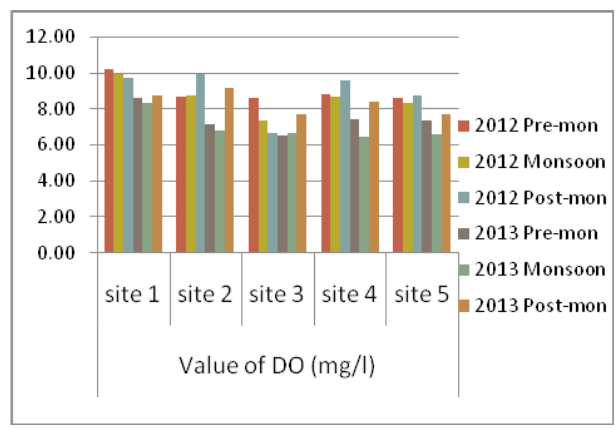

FIG. 6. Seasonal variation in DO.

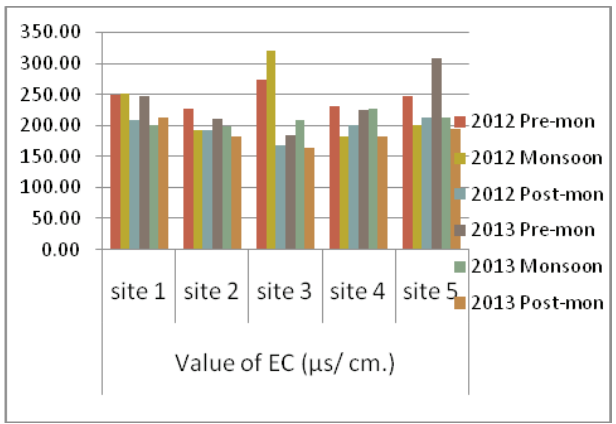

FIG. 3. Seasonal variation in electrical conductivity.

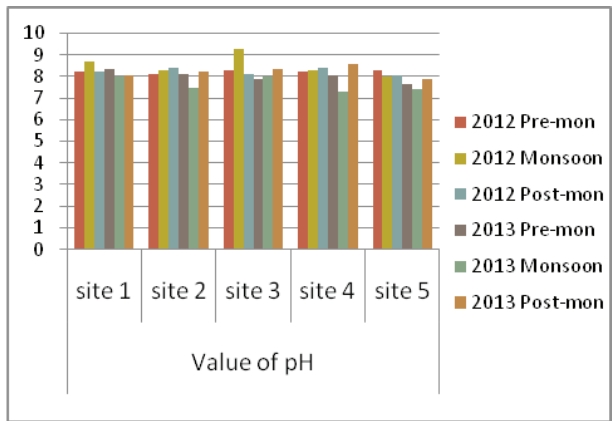

FIG. 5. Seasonal variations in $\mathrm{pH}$.

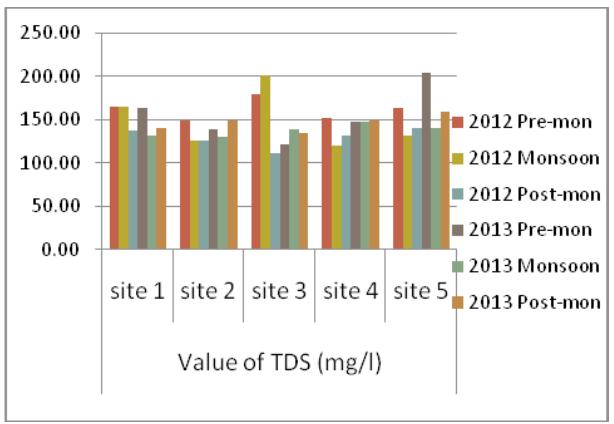

FIG. 7. Seasonal variation in TDS. 


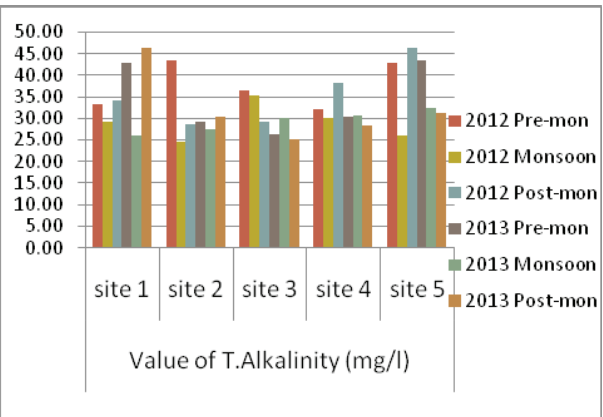

Fig. 8. Seasonal variation in total alkalinity.

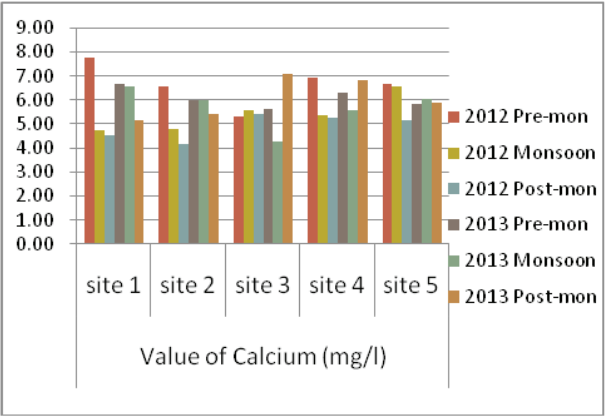

FIG. 10. Seasonal variation in calcium.

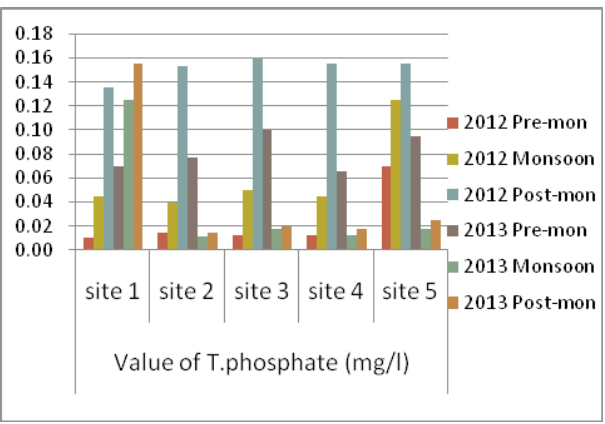

FIG. 12. Seasonal variation in chloride.

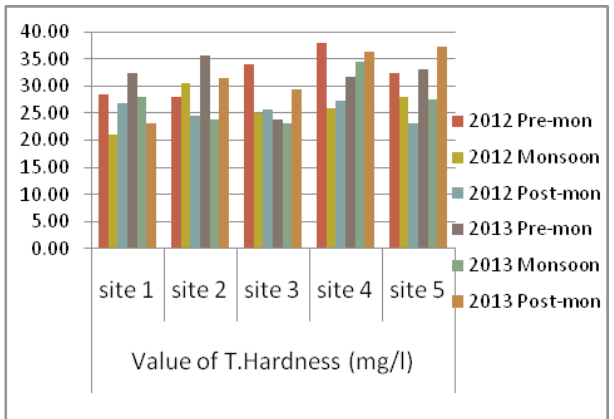

Fig. 9: Seasonal variation in total hardness.

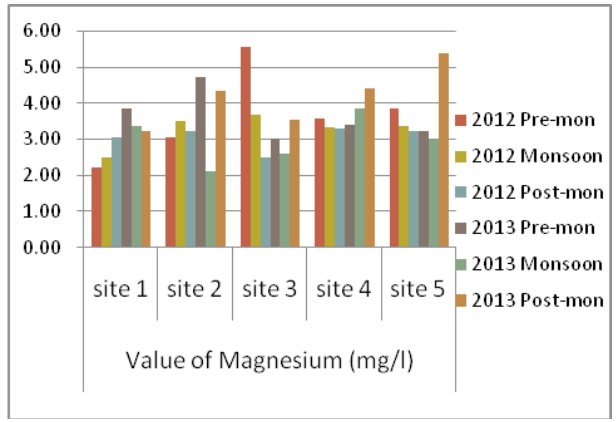

FIG.11. Seasonal variation in magnesium.

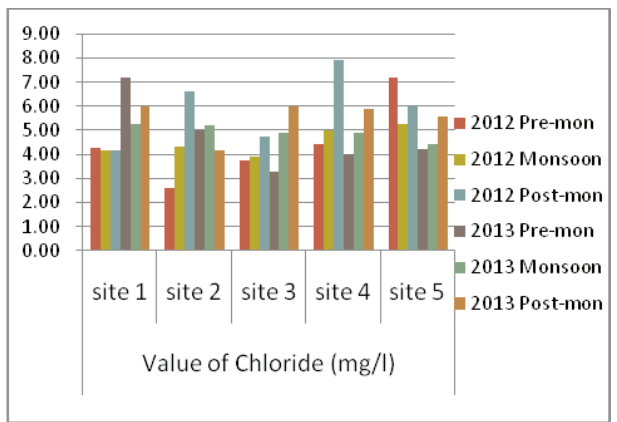

FIG. 13. Seasonal variation in phosphate. 


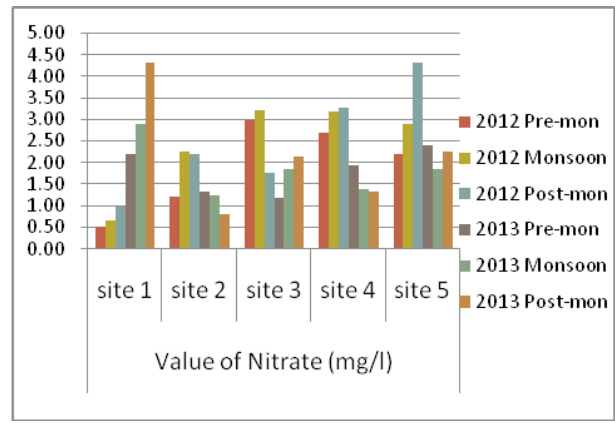

FIG. 14. Seasonal variation in nitrate.

\section{Correlation (r) between different parameters of Melamchi River: 2012 and 2013}

Pearson's correlation coefficient $\left(\mathrm{r}^{2}\right)$ between every parameter pairs in computed by taking the seasonal mean value of collected samples from 2012 to 2013. The degree of line association between any two of the water quality parameters as measured by the simple correlation coefficient $(r)$ is presented in table- 3 and 4 as $13 \times 13$ correlation matrix. R2value $\geq|0.7|$ is statistically significant $(p \leq 0.05)$ at 8 degrees of freedom.

Water temperature showed positive correlations with turbidity. The conductivity showed positive correlation with TDS. Water shows significant conductivity when dissolved salts are present. Dilution of water during rain depletes the EC value of water. There was a positive correlation of EC with $\mathrm{pH}$, TDS, total hardness and magnesium also. This shows that with increase or decrease in the values of EC; TDS, $\mathrm{pH}$ and alkalinity also exhibit decrease or increase in their values. Hardness of water mainly depends upon the amount of calcium or magnesium salts or both. Magnesium showed positive correlation with hardness. Total phosphate showed positive correlation with chloride and nitrate. Nitrate and phosphate concentrations increase with the increasing proportion of agricultural activity.

TABLE 3. Correlation Coefficient ( $r$ ) among physico-chemical parameters of the Melamchi River in 2012.

\begin{tabular}{|c|c|c|c|c|c|c|c|c|c|c|c|c|c|}
\hline & WT & EC & Turb & $\mathrm{pH}$ & DO & TDS & TA & TH & Cal & Mag & Chlo & TPho & Nitr \\
\hline WT & 1 & & & & & & & & & & & & \\
\hline EC & -0.03 & 1 & & & & & & & & & & & \\
\hline Turb & $\mathbf{0 . 6 9}$ & -0.20 & 1 & & & & & & & & & & \\
\hline pH & 0.18 & $\mathbf{0 . 6 8}$ & -0.20 & 1 & & & & & & & & & \\
\hline DO & -0.49 & -0.04 & -0.22 & -0.04 & 1 & & & & & & & & \\
\hline TDS & -0.07 & $\mathbf{1 . 0 0}$ & -0.21 & $\mathbf{0 . 6 4}$ & 0.00 & 1 & & & & & & & \\
\hline TA & -0.32 & 0.32 & -0.38 & -0.09 & 0.00 & 0.35 & 1 & & & & & & \\
\hline TH & -0.06 & 0.14 & -0.04 & -0.29 & -0.09 & 0.16 & 0.03 & 1 & & & & & \\
\hline Cal & -0.02 & 0.27 & 0.10 & -0.21 & -0.07 & 0.29 & 0.21 & 0.49 & 1 & & & & \\
\hline Mag & 0.16 & 0.36 & 0.11 & 0.03 & -0.21 & 0.37 & 0.20 & 0.56 & -0.11 & 1 & & & \\
\hline Chlo & 0.05 & -0.32 & 0.11 & -0.08 & 0.18 & -0.31 & 0.15 & -0.09 & -0.16 & 0.00 & 1 & & \\
\hline TPho & -0.08 & -0.55 & 0.21 & -0.21 & -0.08 & -0.56 & 0.01 & -0.48 & -0.48 & -0.25 & $\mathbf{0 . 6 2}$ & 1 & \\
\hline Nitr & 0.48 & -0.02 & 0.34 & -0.01 & -0.38 & -0.04 & 0.24 & 0.09 & -0.16 & 0.52 & 0.42 & 0.27 & 1 \\
\hline
\end{tabular}


TABLE 4. Correlation Coefficient ( $r$ ) among physicochemical parameters of the Melamchi River in 2013.

\begin{tabular}{|c|c|c|c|c|c|c|c|c|c|c|c|c|c|}
\hline & WT & EC & Turb & $\mathrm{pH}$ & $\mathrm{DO}$ & TDS & TA & TH & Cal & Mag & Chlo & TPho & Nitr \\
\hline WT & 1 & & & & & & & & & & & & \\
\hline EC & 0.03 & 1 & & & & & & & & & & & \\
\hline Turb & $\mathbf{0 . 7 4}$ & 0.07 & 1 & & & & & & & & & & \\
\hline pH & -0.37 & -0.36 & -0.40 & 1 & & & & & & & & & \\
\hline DO & -0.16 & -0.14 & -0.11 & $\mathbf{0 . 6 7}$ & 1 & & & & & & & & \\
\hline TDS & -0.13 & $\mathbf{0 . 8 1}$ & -0.19 & -0.06 & 0.18 & 1 & & & & & & & \\
\hline TA & -0.17 & $\mathbf{0 . 7 1}$ & -0.15 & -0.05 & 0.30 & $\mathbf{0 . 6 4}$ & 1 & & & & & & \\
\hline TH & -0.22 & 0.18 & -0.10 & 0.20 & 0.20 & 0.52 & 0.00 & 1 & & & & & \\
\hline Cal & 0.17 & -0.04 & 0.33 & -0.03 & -0.02 & 0.04 & -0.22 & 0.53 & 1 & & & & \\
\hline Mag & -0.14 & -0.06 & 0.00 & 0.26 & 0.45 & 0.32 & 0.11 & $\mathbf{0 . 7 1}$ & 0.23 & 1 & & & \\
\hline Chlo & 0.06 & -0.05 & 0.00 & 0.40 & 0.43 & 0.08 & 0.32 & 0.19 & 0.30 & 0.51 & 1 & & \\
\hline TPho & -0.19 & 0.32 & 0.20 & 0.14 & 0.24 & 0.06 & 0.48 & -0.27 & -0.19 & -0.23 & 0.01 & 1 & \\
\hline Nitr & 0.20 & 0.25 & 0.25 & 0.07 & 0.29 & 0.15 & $\mathbf{0 . 6 1}$ & -0.26 & -0.15 & 0.02 & 0.41 & $\mathbf{0 . 6 9}$ & 1 \\
\hline
\end{tabular}

WT- Water temperature, EC- Electrical Conductivity, Turb-Turbidity, TDS- Total dissolved solids, TA-Total alkalinity, TH- Total hardness, Cal-Calcium, Mag- Magnesium, Chlo-Chloride, TPho- Total phosphate, Nitr-Nitrate.

Temperature started to increase from February, reached at peak during monsoon (May-June) and then dropped suddenly in July/August, mainly due to rainfall and mixing of incoming cold water. Sharma et al. (2007) reported variation in temperature due to variation in altitude, which is characteristic feature of streams in the mid-hills with origin from the higher mountains. Ghimire et al. (2013) recorded this type of difference in high-altitude Rivers due to climate change. Electrical conductivity showed marked seasonal variation, being maximum in pre-monsoon and minimum during post-monsoon season. Dissolved salts such as sodium chloride and potassium chloride mostly influence the electric conductivity. It increased from January to June and then decreased abruptly in July and August due to dilution effect caused by rain and floodwater. The accumulation of dissolved salts due to high rate of evaporation of water shows high electrical conductivity value during pre-monsoon and low in monsoon. In warm month's evaporation in water bodies, decrease the total quantity of water, causing increase in electrical conductivity (Hussain et al., 2013). Mirza et al. (2013) and Kolo \& Oladimeji (2004) reported similar findings.

High value of turbidity in the monsoon season was due to the maximum agitation of water caused by rainfall. Dagaonkar \& Saxsena (1992) also support this finding. Garg et al. (2006) have also reported high turbidity during rainy season. Silt, clay and other suspended particles contribute to the turbidity value in rainy season, while during winter and summer seasons settlement of silt, clay results low turbidity. Fluctuation in $\mathrm{pH}$ value indicates organic loads in water. Chisty (2002) reported that $\mathrm{pH}$ value is very important for plankton growth. The TDS values followed the same trend as conductivity. It has been seen that a linear relationship existed between TDS and EC. Samal (2001) and Singh et al. (2010) also observed a similar trend of TDS. The high dissolved oxygen in post-monsoon may be due to turbulence and oxygenation resulting from high rainfall and increased water flow. Alkalinity means the concentration of anions. It is important for fish and aquatic life because it protects or buffers against $\mathrm{pH}$ changes. Total alkalinity of water is due to presence of mineral salts in it. It is pri- 
marily caused by the presence of carbonate and bicarbonate ions. Total alkalinity also followed almost same pattern as Total Hardness, being highest in pre-monsoon and lowest in monsoon. Hussain et al. (2013) reported same pattern. A minimal variation in hardness was found in both the years. Hardness is mainly concerned with the concentration of calcium and magnesium ions. Low content of calcium and magnesium resulted into softness of Melamchi River, also supported by EMP/MWSP (2009). Hujare (2008), Hussain et al. (2013) reported high total hardness during summer than rainy season and winter season. The chloride concentration serves as an indicator of pollution by sewage. Increase in chloride in monsoon may be due to the domestic discharge and agricultural runoff where phosphate-containing fertilizers are used. Higher concentration of phosphate rarely occurs, because plants and bacteria rapidly up take it when it enters in water system. In general, phosphorous is an essential nutrient to living organisms. Nitrate (NO3-) is one of the important nutrients in water body and is the common form of nitrogen in natural water. Plants and microorganisms reduce nitrate into nitrite but nitrite ion quickly oxidize back to nitrate once it re-enters the water. Natural sources of nitrate are animal debris, plant decay, and igneous rock. In present analysis high turbidity, increase in chloride, phosphate and nitrate values, indicated mixing of organic waste load particularly sewage contamination and anthropogenic use. However, in the present study analysis of the most of the parameters were in acceptable range of WHO (2011), except turbidity.

\section{ACKNOWLEDGMENTS}

This work is a part of research done for the degree of Ph.D. Authors thank Melamchi Water Supply Development Board for their co-operation in the field study and for providing necessary Lab facilities. Mr Resham Bania, Patan Campus, Tribhuvan University fo $r$ GIS support and Mr. Chitra B.Baniya, Central Department of Botany, Tribhuvan University for statistical guidance.

\section{REFERENCES}

APHA (2005) Standard methods for the examination of water and wastewater. American Public Health Association, Washington, DC, USA (21st edition).

CHISTY, N (2002) Studies on biodiversity of freshwater zooplankton in relation to toxicity of selected heavy metals. Ph. D. dissertation, M.L Sukhadia Univeristy Udaipur, India.

DAGAONKAR, A; SAKSENA, DN (1992) Physico-chemical and biological characterization of temple tank, Kaila Sagar, Gwalior, Madhya Pradesh. J. Hydrobiology 8 (1): 11-19.

EMP/MWSP (2009) Environment mManagement Program, MWSDB: Melamchi Water Supply Development Board-Report.

GARG, R K; SAXSENA, D N; RAO, RJ (2006) Assessment of physico-chemical water quality of Harsi Reservoir, district Gwalior, Madhya Pradesh. Journal of Ecophysiology and occupational Health 6: 33-40.

GHIMIRE, N P; JHA, P K; CARAVELLO, G (2013) Physico-chemical parameters of high-altitude rivers in the Sagarmatha (Everest) National Park. Nepal Journal of Water Resource and Protection 5: 761-767 http://dx.doi.org/10.4236/jwarp.2013.58077, <http://www.scirp.org/journal/jwarp>. Downloaded on 5/5/2015.

HAYNIE, M M; BURKE, G F; BALDYS, S (2011) Chloride control and monitoring program in the Wichita River Basin, Texas. 1996-2009: U.S. Geological Survey Fact Sheet 2011-3018, USA; 4 p. 
HUJARE, M S (2008) Seasonal variation of physico-chemical parameters in the perennial tank of Talsande, Maharashtra. Ecotoxicology and Environmental Monitoring 18(3): 233-242.

HUSSAIN, A; SULHERIA, A Q K; MUHAMMAD, E; MAQBOOL, A (2013) Monthly variations in physicochemical parameters of a flood plain reservoir on River Ravi near Balloki Headworks (Pakistan) Biologia (Pakistan) 59(2): 371-377.

KOLO, R J; OLADIMEJI, AA (2004) Water quality and some nutrient levels in Shiroro Lake, Niger State, Nigeria. Journals of Aquatic Sciences 19 (2): 99-106.

MIRZA, Z S; MUHAMMAD, S N; BEG, M A; MALIK, I (2013) Spatial and temporal fluctuations in the physicochemical limnology of Mangla Dam (Pakistan). Pakistan Journal of Zoology 45(3): 679-686.

PRADHAN, U K; SHIRODKAR, P V; SAHU, BK (2009) Physicochemical evaluation of its seasonal changes using chemometric techniques. Current Science 96(9): 1203-1209.

SAMAL, N R (2001) Physiological and biological characteristics of water of lake Rabindra Sarovar, the National Lake, Kolkata, India. Thesis submitted to school of Water Resource Engineering, Jadavpur University, Kolkata, India.

SHARMA, M R; GUPTA, A B (2004) Seasonal variation of physico-chemical parameters of Hathli stream in outer Himalayas. Pollution Research 23 (2): 265-270.

SHARMA, S; BANJADE, S; BHANDARI, R (2007) Impact of Khimti - I Hydropower Project in Nepal on the ecological status of river and fishermen's livelihood. International Conference on Small Hydropower - Hydro Sri Lanka, 22-24 October.

SRIDHAR, R; THANGARADJOU, T; SENTHIL, K S; KANNAN, L (2006) Water quality and phytoplankton characteristics in the Palk Bay, southeast coast of India. Journal of Environmental Biology 27: 561-566.

SINGH, M R; GUPTA, A; BEETESHWARI, K (2010) Physico-chemical factors of water samples from Manipur River System, India. Journal of Applied Science and Environmental Management 14(4): 85-89.

SRIVASTAVA, N; HARIT, G; SRIVASTAVA, R (2009) A study of physico-chemical characteristics of lakes around Jaipur, India. Journal of Environmental Biology 30(5): 889-894.

THAPA, G B; PAL, J (2014) Evaluation of physico-chemical characters of Singhia and Budhi rivers in Sunsari and Morang Industrial corridor, Nepal. International Journal of Advanced Research in Biological Sciences 1(8): 104-112 < www.ijarbs.com >. Downloaded on 9/10/2015.

WHO ( 2011) Guidelines for drinking water quality Vol. 1. Recommendations, World Health Organization, Geneva, Switzerland (3rd edition). 